\title{
CHARLIE HEBDO: SOBRE A DEMOCRACIA FRANCESA
}

\author{
CHARLIE HEBDO: ON FRENCH DEMOCRACY
}

\author{
JORDAN MICHEL MUNIZ \\ ( Universidade Federal de Santa Catarina, Brasil)
}

\begin{abstract}
RESUMO
Discutirei os assassinatos no jornal Charlie Hebdo a partir de questões ligadas à religião, à democracia e à liberdade, nesta ordem. Primeiro, irei apresentar aspectos sociais e econômicos da vida dos imigrantes na França, seguidos por fatos da história da dominação imposta aos países abandonados pelos imigrantes. Depois, vou recorrer a Judith Butler e à teoria do discurso para mostrar como a exclusão social foi materializada na França, e defender que uma grave desigualdade política cinde a sociedade francesa, originando revoltas. Problemas de caráter racial foram convertidos em contenda religiosa, fixando identidades antagônicas que barram a interação. Por último, irei apontar a necessidade de transformação da democracia francesa, de modo a dar cidadania efetiva a todos os imigrantes. Converter o conflito religioso atual em embate político permitirá estender os direitos sociais e humanos a todos e valorizar as liberdades democráticas. Talvez por este caminho venha a ser possível a França e outros países europeus construírem uma sociedade realmente igualitária em termos sociais e políticos, com liberdades plenas para todos.
\end{abstract}

Palavras-chave: Democracia. Igualdade. Teoria do discurso. Racismo. Religião.

\begin{abstract}
I will discuss the murders associated to Charlie Hebdo newspaper starting from issues related to religion, democracy and freedom, in that order. First, I will present socioeconomic aspects connected to immigrants' life in France, continuing with events about the history of domination imposed on countries forsaken by immigrants. Next, I use Judith Butler and the discourse theory to show how France materialized the social exclusion, arguing that a strong political inequality splits French society, which is cause for rebellions. Racial character problems have been converted into religious strife, setting antagonistic identities in a way that interaction became impossible. Finally, I point out the need for transformation of French democracy aiming an effective citizenship for all immigrants. Convert the current religious conflict in political confrontation should enable expand the social and human rights for all, prizing democratic freedoms. Perhaps on this path will be possible for France and other European countries to build a truly egalitarian society in social and political terms, with full freedoms for all.
\end{abstract}

keywords: Democracy. Equality. Discourse theory. Racism. Religion.

\section{Introdução}

Por que a defesa dos valores democráticos costuma começar associando a democracia à liberdade, e não à igualdade? Os postulados proeminentes da liberal democracia liberdade e direitos humanos, frequentemente são os únicos salientados quando se repudiam agressões à humanidade. Atacou-se uma liberdade no Charlie Hebdo, mas o produto da liberdade é a causa do atentado? Foram mesmo os cartuns o motivo? Neste artigo tratarei do tema da liberdade, democracia e religião evitando a via predominante. Desde o início inverto 
a ordem dos elementos deste debate: começo pela religião, para depois verificar o efeito da proeminência desta na democracia, e só então tratar das liberdades.

Defendo que mudar a disposição dos termos não conduz à justificação do terrorismo; antes, pode adequar a investigação filosófica à sequência fática. A argumentação terá como eixo a desigualdade política, configurada nas restrições que condicionam a existência dos imigrantes. A falta de inclusão efetiva é destacada ao analisar as circunstâncias dos atentados, sem qualquer intenção de desculpar os dezessete assassinatos cometidos em Paris por muçulmanos radicais.

$\mathrm{Na}$ primeira parte delinearei o quadro socioeconômico adverso em que vivem os imigrantes, mostrando a inferioridade de tal situação frente à maioria dos franceses, especialmente quanto às oportunidades educativas e profissionais. Complementarei este exame com antecedentes históricos, revendo causas do processo migratório que força milhões ao exílio e à inserção numa cultura estranha.

Na seção seguinte recorrerei a Judith Butler e à teoria do discurso para mostrar a corporificação da exclusão social na França, efetuada por formações discursivas que utilizam a religião para dissimular o racismo. Desta maneira a igualdade que a Constituição garante a todos é desrespeitada. Não se discriminam abertamente os corpos escuros: os rejeitados são materializados como corpos muçulmanos. O apartheid não reconhecido é acirrado quando se exige a república laica sem a contrapartida da igualdade sociopolítica. A fixação de identidades opostas abriu um abismo na sociedade francesa.

$\mathrm{Na}$ última parte insistirei que a crise da democracia francesa origina-se do deslocamento dos conflitos daquilo que constitui propriamente o político (MOUFFE 2005a-b) para o terreno da religião. Há necessidade de repensar a formação do povo, e de instituições democráticas mais inclusivas. Só então me ocuparei daquilo que a mídia denuncia como barbarismo: desrespeito à liberdade de expressão. Liberdade e direitos humanos são conquistas cujo significado deve ser aplicável à coletividade.

\section{Estratos sociais — povo heterogêneo}

Quando os cartunistas do Charlie Hebdo foram chacinados a imprensa ocidental retratou uma comunidade mundial estarrecida e solidária na dor. A brutalidade do ato foi ampliada pela percepção de que os tiros disparados feriam a liberdade de expressão de cada um, e que a intolerância atingia um pilar da democracia, na cidade que tantas vezes protagonizou a luta do povo por seus direitos. Assim, soa 'natural' discutir o acontecido como 
uma questão de liberdade, democracia e religião.

Minha abordagem indireta do tema apoia-se em raciocínios menos evidentes. Ninguém acredita que os autores do crime sejam fundamentalistas ímpares, os únicos capazes de tal gesto. Há um grave problema sociopolítico subjacente que exige atenção. Pouco ajuda imaginar que existam outras pessoas integradas à Europa com igual disposição homicida, mas considerar que tal propensão deriva da incapacidade de entenderem e aceitarem os preceitos democráticos, devido à origem não europeia. Essa visão simplista propõe identificar potenciais agressores, tratando a segurança pública e a garantia da liberdade de imprensa apenas no âmbito policial ou da Guerra ao Terror. A investigação e policiamento defensivos têm serventia emergencial, mas como profilaxia do mal temido tornam-se inócuos, possibilitando inclusive o agravamento da situação, na medida em que forem sentidos como segregação. Segregação ampliada, para reiterar a linha argumentativa que seguirei. Corre-se o risco de tratar aqueles que têm características estrangeiras como inimigos, visando proteger o povo. Sabe-se como isto termina e quais são os frutos da xenofobia. Que povo?

Este discurso é similar ao do povo homogêneo de Schmitt, para quem era necessário "eliminar ou aniquilar o heterogêneo" (SCHMITT 1996, p. 10). Tomar tal atitude frente às mortes seria assumir como dado justamente o que precisa ser explicado. Schmitt ignorou o processo formativo da igualdade política, que possibilita homogeneidade ${ }^{1}$ a um povo. O que é o povo francês hoje? É preciso perguntar se os tiros em Paris opõem-se ao ideário da Revolução Francesa, ou se de forma cruel eles remetem ao sonho popular de Liberdade, Igualdade e Fraternidade, para todos. Aliás, naquela época houve quem clamasse apenas pelo último elemento: Fraternité, ou la Mort! O sentido era 'ou você está comigo ou contra mim' — ou irmão, ou inimigo, evidenciando o antagonismo social dos desiguais. Atentados e demonstrações de preconceito parecem repor tal questão. Aliás, a reação Je suis Charlie não é apelo à fraternidade? Não marca uma fissura? Não separa quem está com Charlie daqueles que não estão nem aí, ou são contra Charlie?

\section{Imigrantes e franceses - desigualdades socioeconômicas}

Há semelhanças de origem nos estratos sociais mais baixos da França. São majoritariamente provenientes do Magrebe, com menor participação do Maxerreque ${ }^{2}$, os habitantes das Zones Urbaines Sensibles ${ }^{3}$ (ZUS), também conhecidas como 'no-go', onde moram aproximadamente cinco milhões de imigrantes ou descendentes destes nascidos na 
França. Famílias dividem apartamentos em prédios deteriorados, comparáveis a enormes cortiços. Em algumas ZUS a ausência do Estado permite que a Lei Islâmica (shariah, que não separa religião e Direito) sobreponha-se à lei oficial, sendo usada para resolver disputas entre moradores. Aí reside parcela significativa dos cerca de dez por cento de muçulmanos incluídos nos 66 milhões de franceses. As novas gerações prendem-se pouco aos costumes trazidos das ex-colônias africanas. Ocorreu incorporação à cultura local, e de modo geral os jovens não cultuam a religião dos antepassados. Todavia, a inserção é parcial, na medida em que não podem usufruir de fato da moderna sociedade de consumo, devido às limitações de renda. O desemprego ou subemprego é elevado. O baixo nível de escolaridade e a fraca qualidade da educação impedem o acesso às melhores universidades e, consequentemente, aos melhores salários e bons empregos. O círculo vicioso estreita as possibilidades de progresso social.

A discriminação não se vincula somente à ancestralidade estrangeira. Se o candidato for africano, mas cristão, terá chance duas vezes e meia maior de conseguir emprego do que um muçulmano com as mesmas qualificações, conforme pesquisadores da UCLA, Stanford e Sorbonne (ADIDA; LAITIN; VALFORT 2010). Além disto, Boltanski e Chiapello exemplificaram meios pelos quais processos seletivos assumem critérios segregadores não explícitos, exigindo fotografias, histórico escolar, ou endereço residencial. São dados aparentemente triviais, porém permitem saber a cor da pele, onde a pessoa passou a juventude e se ela mora numa ZUS. "Numa situação em que 'não há emprego para todos', são sempre os mesmos os não selecionados, o que só pode aumentar suas deficiências e criar barreiras cada vez mais difíceis de transpor entre os diferentes 'segmentos' do salariato" (BOLTANSKI; CHIAPELLO 2009, p. 261). Encontram-se abundantes "evidências de discriminação no trabalho e no mercado imobiliário" (PONS; LIEGEY 2013, p. 7). Critérios ilegítimos minam a confiança na justiça social, comprometendo a adesão dos excluídos aos valores republicanos de igualdade e liberdade:

Assim, não é exagerado considerar que se pode definir uma sociedade (ou um estado de sociedade) pela natureza das provas que ela adota e por meio das quais se efetua a seleção social das pessoas, bem como pelos conflitos referentes ao caráter mais justo ou menos justo dessas provas (BOLTANSKI; CHIAPELLO 2009, p. 67).

No momento em que os tiros foram disparados no Charlie Hebdo a maioria dos descendentes de imigrantes suportava uma integração defectiva à vida na França. Sentiam-se como franceses de segunda categoria: incorporaram os costumes da pátria onde nasceram, mas não foram assimilados pela nação. Há uma questão de falha na identidade, à qual 
retornarei. De qualquer modo, tal assimetria e incompletude contribuíram grandemente para a série de tumultos urbanos de outubro e novembro de 2005, causados pelo sentimento de abuso policial na morte de dois jovens de origem árabe. Os distúrbios duraram vinte noites (8973 carros incendiados, 2888 presos). Análises destes fatos não associaram religião à revolta ${ }^{4}$. Pelo contrário, evidências mostraram que instituições religiosas muçulmanas exerceram pouca ou nenhuma influência nos amotinados, mesmo quando tentaram apaziguar os ânimos. Contudo, isto não impediu que a depredação fosse registrada como ação de muçulmanos incivilizados por vasto contingente da opinião pública. Repito: a quase totalidade dos manifestantes era nascida na França, mas vista como estrangeira devido à origem étnica e provável religião. O sentimento de exclusão dos direitos sociais foi agravado pelas leis que vedam o uso ostensivo de símbolos religiosos. Embora formalmente amplas na redação, as normas têm claro intuito de proibir partes do vestuário islâmico em escolas ou espaços públicos. A roupa encobre o crucifixo; para o muçulmano, o traje é o símbolo.

Em conjunto, estes fatores provocam contínua frustração dos sonhos de cidadania plena, de participação no consumo, na vida boa. A propaganda chama a todos, mas o mercado e a sociedade discriminam, erguem barreiras injustas e difíceis de transpor. Apesar da equitativa proteção jurídica formal, ter a pele escura ou ascendência corânica, principalmente entre os mais jovens, implica um misto de conformismo e rebeldia, por uma vida com oportunidades muito desiguais frente aos franceses de tez clara. Este ambiente cria recrutas para o ódio. Se os desejos são irrealizáveis, por que não destruir a promessa vazia? A desilusão quanto às expectativas de progresso facilita o discurso fundamentalista, que oferece um caminho para a glória ou, pelo menos, vingança. É do dia a dia sem perspectivas positivas que surge a disposição para o sacrifício heroico. A existência ruim engendra a causa grandiosa. Este é um aspecto essencial que a França terá que solucionar se quiser paz social.

A tarefa esbarra na falta de recenseamento para planejar ações adequadas: veda-se ao Estado coletar dados relativos à fé ou origem étnica. Com intenção igualitária equivocada, a Constituição ${ }^{5}$ proíbe questionários sobre tais características indicadoras das diferenças entre as pessoas. Não se promove a igualdade ignorando o que há de diferente. Em entrevista após a supracitada pesquisa conjunta com Adida e Valfort, Laitin ressaltou que "sem estas informações [...] é impossível entender e corrigir as situações nas quais os cidadãos estão sendo discriminados":

Os franceses têm uma crença muito forte de que as suas instituições republicanas são cegas à etnicidade e à religião, e que estas instituições são um antídoto à discriminação. [...] Nós agora podemos lhes dizer que os resultados do nosso 
trabalho mostram que a sociedade não é cega à religião e que a recusa deles em coletar dados permitirá que a discriminação continue. Ocultar-se atrás do véu do republicanismo não é uma solução para o problema da discriminação na França (LAITIN apud GORLICK 2010).

O sucesso financeiro vem dos melhores empregos, reservados aos frequentadores das Grandes Écoles, inacessíveis a quem teve fraca formação. Na segregação das Zones Urbaines Sensibles há educação precária com evasão escolar elevada, e metade dos jovens está desempregada ${ }^{6}$. Insisto no já dito: é um círculo sem virtudes, aprisionante. O depoimento de Laitin termina com afirmação paradoxal, talvez tentando não ofender o orgulho francês: "Eu não quero dizer que os franceses fracassaram com o republicanismo. Mas está claro que eles não têm concretizado seus ideais" (LAITIN apud GORLICK 2010). Estas deficiências revelam-se elementos-chave na acusação dos assassinos dos caricaturistas, caso haja preocupação com o contexto factual, evitando a rigidez maniqueísta que estabelece de antemão o bem e o mal. Vale lembrar as palavras de Žižek ao tratar dos protestos de 2005: "Deve-se ter em mente que a tarefa do filósofo não é propor soluções, mas reformular o próprio problema, para mudar a estrutura ideológica na qual até aqui se percebia o problema" (ŽIŽEK 2005, p. 189).

Meu objetivo com esta digressão não é apresentar um exame etnográfico ou sociológico da aculturação imigratória na França. Os dados acerca deste segmento populacional visam aclarar a indagação prévia sobre quem é o povo da democracia francesa hoje - o povo soberano, o sujeito da igualdade e liberdade, cujos direitos comuns geram valores compartilhados.

$\mathrm{O}$ acolhimento dos imigrantes parece expiação dos males praticados pela França na época imperialista. Entretanto, os ex-colonos são rejeitados, embora o envelhecimento da maioria branca, com baixas taxas de natalidade, aponte para uma dependência progressiva do trabalho das novas etnias, cujo percentual na população cresce. Todavia, nem a culpa passada nem a necessidade futura produzem aceitação autêntica. Ao contrário, propõe-se com frequência: (1) diminuir a proteção social e (2) endurecer as exigências feitas aos imigrantes.

Em relação à primeira medida, julgam-se as políticas sociais muito atrativas, favorecedoras das famílias polígamas, e busca-se endurecer o sistema. É evidente que ao reduzir os benefícios aumenta-se ainda mais o sofrimento e a pobreza, quando o imperativo seriam medidas afirmativas compensatórias que propiciassem inclusão. Mas qualquer política de cotas é obstruída pelo citado impedimento legal de "coletar dados enfatizando a origem, raça ou religião dos indivíduos interessados" (CANET; PECH; STEWART 2008, p. 15). 
Quanto à segunda proposta, quer-se obrigar quem vive em solo francês a adotar a cultura local, aí incluída a liberdade de expressão. Contraditoriamente, nega-se assim o que é prescrito, a livre expressão das pessoas forçadas à submissão em nome das liberdades do cidadão: "é sabido como nos países coloniais a equivalência entre 'direitos do Homem' e 'valores europeus' era uma forma frequente e efetiva de construir discursivamente a aceitabilidade da dominação imperialista” (LACLAU; MOUFFE 2001, p. 116). Repete-se em nova roupagem a postura senhorial de superioridade racional, esclarecida, que autoriza o domínio: "De volta aos tempos do império colonial, quando as autoridades públicas costumavam ensinar aos povos submetidos pela força ao mando francês os méritos da Declaração dos Direitos do Homem de 1789, enquanto negavam a humanidade destes" (CANET; PECH; STEWART 2008, p. 16). Aqui reaparece um tópico central da minha argumentação: forçar os imigrantes a abraçarem a cultura ocidental e sua liberdade de expressão é tratar o efeito e não a causa. Por isto optei por uma leitura indireta do massacre no Charlie Hebdo. O que precisa ser feito é obrigar a democracia francesa a ser democrática, visando não produzir a contínua exclusão dos mesmos grupos. Daí o comentário de Baudrillard sobre as rebeliões de 2005:

\begin{abstract}
$\mathrm{Na}$ realidade, a sociedade francesa - e de modo geral, a europeia - segrega dia após dia, mediante seu processo de socialização, a discriminação implacável da qual os imigrantes são as vítimas indicadas, embora não as únicas. Esta é a mudança na barganha desigual da "democracia". Tal sociedade enfrenta uma prova mais dura que qualquer ameaça exterior: a da sua própria ausência, da sua perda de realidade. Logo será definida somente pelos corpos estrangeiros que rondam sua periferia: aqueles que ela expeliu, mas que agora a estão expulsando de si mesmos (BAUDRILLARD 2006, p. 6).
\end{abstract}

Insisto que em 2005 a religião não era fator central. Houve subúrbios em que a maioria dos jovens eram filhos de trabalhadores franceses brancos cronicamente desempregados. Aquela insurgência foi uma explosão dos mais pobres contra a persistente exclusão: “integração é algo que não se refere meramente às pessoas de origem estrangeira, mas a todos aqueles que vivem às margens do sistema social e econômico e que têm que se perguntar que valores mínimos eles podem, apesar disto, partilhar com seus concidadãos” (CESARI 2005). O futuro coletivo não será bem construído repetindo a depreciação dos imigrantes.

Proponho examinar diferenças históricas para subsidiar o estudo das desigualdades sociais. Naquelas, têm-se a memória de antigos desrespeitos; nestas, sua reiteração: imigrantes são humanos que não tiveram e não têm voz. 


\section{Vidas insignificantes}

Muitos revolucionários parisienses de 1789, 1848 e, especialmente, os de 1871, deram suas vidas pelo reconhecimento da igualdade política. Não se indagava por que alguém se sacrificava. Olhava-se para a causa, e a motivação despontava na dignidade óbvia do gesto necessário. A entrega era vista como corajoso altruísmo, e os mortos chamados de heróis do povo. Perto do final da Segunda Guerra Mundial os pilotos kamikazes chocaram o mundo com sua bravura desesperada, atirando seus aviões contra navios aliados, fazendo da morte arma contra os oponentes. Porém só recentemente o mundo viu surgirem os homens-bomba, algo incompreensível para o pensamento ocidental, que alimentou gracejos debochados. Ridicularizou-se o 'desprezo' muçulmano pela própria vida, ligando-o a ânsia pelas maravilhosas virgens que aguardariam o mujahid $^{7}$ no paraíso.

Assim se repete o desrespeito, o distanciamento emotivo, a falta de reconhecimento dos valores do outro, este olhar superior que faz do outro um bárbaro sem buscar compreender sua insatisfação ou desespero. É fácil menosprezar o fundamentalista, seus livros sagrados e suas citações: “Eu vim ao Profeta [...] e disse: 'Oh Mensageiro de Alá, qual Jihad é melhor?' Ele disse: ‘[Aquela de um homem] de quem o sangue é derramado e seu cavalo é ferido"” (SUNAN IBN MAJAH) ${ }^{8}$. Pelos textos infere-se que os muçulmanos estão dispostos a imolar-se pela glória de uma religião essencialmente belicosa. Não há dificuldade em encontrar passagens piores na Bíblia: "Todo que for achado será traspassado e, todo que apanhado, cairá à espada. As suas crianças serão despedaçadas (j) perante seus olhos; as suas casas serão saqueadas, e a mulher de cada um, estuprada" (Isaías 13, 15-16). É iníquo justificar o fragmento bíblico dizendo que está fora de contexto, pois não há alternativa que permita uma exegese decente disto. No entanto, os cristãos não se consideram bárbaros. "L'enfer, c'est les Autres", dizia Garcin em Huis Clos.

Bárbaro aplica-se desde a Antiguidade ao diferente, ao estrangeiro, significando costumes grosseiros, ignorância, estupidez, crueldade. "Bárbaros são aqueles que não reconhecem que os outros são seres humanos como eles" (TODOROV 2010, p. 16). O conceito ainda tem sentido figurado, carrega desdém, atribui deficiência civilizatória. Basta uma rápida incursão à história para perceber a impropriedade. Da álgebra à astronomia e à dominação moura na Península Ibérica, na Idade de Ouro Islâmica, há variados exemplos de extensa sabedoria combinada com temperamento tolerante em relação à fé alheia, generosidade não retribuída após a reconquista pelos reis católicos. O Renascimento não teria sido possível sem a preservação e cultivo de importante porção dos conhecimentos e textos 
gregos pelos povos do Oriente. Tudo isto é tão sabido quanto descuidado nos preconceitos que parcela expressiva da civilização agora hegemônica manifesta às culturas islamizadas. Entretanto, não é o passado remoto dos seguidores de Alá que importa. Por isto, abandono exemplos distantes e volto aos séculos recentes, nos quais a Europa impôs ao Levante Mediterrâneo ampla dominação espoliadora, baseada na escravidão dissimulada de povos inteiros.

Os países europeus na costa atlântica — da Alemanha a Portugal, Inglaterra incluída - mais a Itália, saquearam a África, muitos mantendo colônias ainda durante a década de 1960, ou até 1980. Marrocos e Tunísia obtiveram independência da França apenas em 1956; Argélia, em 1962. No Oriente Médio os europeus fizeram de tudo. Durante a Primeira Guerra Mundial, nutriram com promessas de autonomia o despertar do nacionalismo árabe, levando os povos da região a se engajarem no combate ao Império Otomano. Quando a paz foi selada, os árabes descobriram a traição franco-britânica, com a perfídia do Acordo Sykes-Picot (denunciado por Lenin), pelo qual franceses e ingleses redesenharam a geografia política usando a autoridade da Liga das Nações, e criaram o moderno Oriente Médio. Deste modo, dividiram entre si a guarda de interesses petrolíferos, sob a forma de mandatos, com a pífia desculpa de que a região não estava pronta para ser independente e responsável pelo próprio destino. Reproduziam assim a tese da superioridade pregada por Mill em relação as "dificuldades iniciais que se encontram nas vias do progresso espontâneo", como justificativa para "um governante inteiramente imbuído do espírito do aprimoramento fazer uso de quaisquer expedientes" para auxiliar o povo atrasado, desprovido da "maturidade das suas faculdades" (MILL 2000, p. 18). É o discurso do bom déspota, tão conveniente ao explorador quanto funesto para o explorado. Destas deslealdades brotou a desconfiança dos árabes com os europeus.

Toda a riqueza do petróleo foi de pouca valia às populações locais. De modo geral, seu usufruto foi exclusividade dos títeres mantidos no poder pelo Ocidente, o maior beneficiário. O despotismo imposto assegurava que o ouro negro continuasse jorrando a baixo custo. Seu efeito mais nocivo foi manter o atraso no desenvolvimento de todo o Oriente Médio, tanto pelo financiamento da opressão interna, quanto pela drenagem e desperdício de recursos. Afinal, aqueles que governavam (e seu círculo íntimo de apoiadores) tinham tudo de que precisavam, inclusive as massas incultas e submissas. Após 1945, predominou a influência norte-americana, com forte incremento da produção petrolífera. Como consequência abriu-se nova frente para a Guerra Fria, trazendo mais tensão ao cotidiano dos povos explorados. 
A pior afronta foi a criação de Israel em terras palestinas, em 1948. A intenção de fundar o Estado judaico já constava na Declaração Balfour ${ }^{9}$, condicionada à derrota dos Otomanos, para a qual os árabes tanto contribuíram sonhando com a autonomia, ou seja, receberam dos europeus um duplo logro. Foi entre refugiados expulsos de suas terras e lares, incapazes de enfrentar o armamento israelense, que o ódio fermentou, originando a OLP Organização para a Libertação da Palestina. Sem esperança de dias melhores, levando vidas insignificantes, sem perspectivas devido à passividade da comunidade internacional, começou a se desenvolver o terrorismo árabe. Para os palestinos, o discurso dos direitos humanos não se aplicava, era mera retórica de decisões da ONU que ninguém fazia Israel respeitar. Liberdade, nunca veio, embora o acordo original previsse a criação do Estado Palestino.

Além do conflito árabe-israelense, países distantes sempre impuseram seus interesses, como ao apoiar no Irã o golpe liderado pelo xá Reza Pahlavi, que reinou com despotismo crescente desde 1941. Derrubado em 1979 pela revolução que alçou a teocracia do aiatolá Khomeini ao poder, os iranianos não tiveram paz: os EUA incitaram (financiando) o Iraque a iniciar uma guerra contra seu vizinho, que durou oito anos, ceifou um milhão e meio de vidas e devastou os dois países. Cito um caso exemplar, entre tantos. O fundamentalismo implantado por Khomeini é importante porque dele se originou o renascimento islâmico, com todas as implicações atuais: Taleban, Al Qaeda, ISIS... A persistência de ambições estrangeiras promovendo mortes na região é patente, como na recente Guerra do Iraque. Novas esperanças desabrocharam na Primavera Árabe, mas esta perdeu várias flores, e ninguém sabe quais frutos vingarão. As interferências externas prosseguem, podando a autodeterminação. A França colabora na Guerra ao Terror: milhares de bombas teleguiadas para cada bomba entregue pessoalmente por terroristas. Quem são os bárbaros? "Bárbaros são aqueles que negam a plena humanidade dos outros. Isto não significa que eles realmente ignorem ou esqueçam tal natureza humana, mas que eles se comportam como se os outros não fossem humanos, ou inteiramente humanos" (TODOROV 2010, p. 16). Será que a multiplicação midiática do Je suis Charlie não expressava um oculto Je suis hégémonie?

[...] há alguma coisa especial no fato de que o Ocidente, tendo estabelecido a lei internacional, encontre razões pelas quais ela não deve ser seguida em certas circunstâncias. Eu acho isto mais perturbador que a sórdida violência de terroristas individuais. Parece-me que não há diferença moral entre o horror infligido por exércitos nacionais [...] e o horror infligido pelos insurgentes. No caso de Estados poderosos a crueldade não é fortuita, mas parte de um esforço para disciplinar populações rebeldes. Presentemente, a crueldade é uma técnica indispensável para manter um tipo particular de ordem internacional, uma ordem na qual as vidas de algumas pessoas são menos valiosas que as vidas de outras e, portanto, suas mortes menos perturbadoras (ASAD 2007, p. 94). 
Não são terroristas as agressões praticadas pelas grandes potências, muito mais mortíferas do que atentados? Não fazem terrorismo Estados que impõem sua vontade violando convenções internacionais e direitos humanos? Tais perguntas são capciosas? Cícero narra comparação semelhante entre tamanho e crime: "Como Alexandre perguntasse a um pirata com que direito infestava o mar com seu barco: 'Com o mesmo', respondeu-lhe, 'com que tu infestas e devastas o mundo"” (CÍCERO 1980, p. 169). Atualmente, infestam o Mediterrâneo os cadáveres de milhares de seres humanos de povos esbulhados, reduzidos à pobreza - afogados buscando vida digna.

Onde houver preocupações humanitárias indagar qual o maior terrorismo não será fútil. Os poucos que alcançam solo europeu não ingressam plenamente no mundo dos direitos universais do homem. Na França democrática, a maioria dos imigrantes vive confinada às margens da democracia, sub-representada ${ }^{10}$ politicamente, não porque lhes falte vontade: dados "sugerem que oferecer uma ajuda aos imigrantes é um modo efetivo de aumentar seu senso de pertencimento e sua participação nas instituições" (PONS; LIEGEY 2013, p. 27). O problema não é saber para que servem os direitos - como a liberdade de imprensa e expressão - mas, para quem? Acima destaquei que a OLP nasceu da desigualdade de meios dos palestinos para uma guerra aberta contra Israel. Afirmei, ainda, que a desesperança favorece os sacrifícios por causas grandiosas. Órfãos de uma França que não os quer como filhos legítimos, a nova geração das ZUS é procurada para adoção por extremistas, com ofertas de nova identidade. Quando se constata que faltam oportunidades sempre para os mesmos, acaba-se acreditando que os direitos pertencem à humanidade; os refugiados e imigrantes, não.

\section{Racismo e religião — identidade e diferença}

$\mathrm{Na}$ França a extrema desigualdade socioeconômica faz com que os direitos dos incluídos não alcancem os excluídos, embora estes tenham o dever de respeitar os direitos daqueles. Esta tem sido a regra para os tolerantes moradores das ZUS. Entretanto, nem todos os imigrantes conseguem suportar passivamente as continuadas injustiças. Viu-se isto nas revoltas de 2005. Direitos constitucionais que se estendem a todos apenas formalmente configuram privilégios, não contribuindo para uma ordem social pacífica. A tensão aumenta quando uma parcela da população, além de não usufruir certos direitos, passa a sentir-se 
desrespeitada pelo uso que os demais fazem destes direitos.

No caso do choque entre a liberdade de imprensa e a acusação de blasfêmia, a exclusividade da expressão livre - pois quem não tem os meios não tem expressão — passou a ser sentida como munição para despojar quem quase não tem bens materiais até da sua dignidade espiritual. Aí pouco importa a real intenção. Tudo piora se por meio do direito for exibida superioridade, na atitude que não se satisfaz com o gozo da melhor posição social, mas que precisa deixar claro seu desprezo por quem é mantido embaixo. Quando isto aconteceu não fez mais diferença saber se o Corão e Maomé eram realmente cultuados e importantes, ou se a espiritualidade era o último refúgio dos desassistidos. Neste ponto, para alguns a religião virou arma, pela qual podiam marcar o antagonismo afirmando uma diferença, uma identidade, um ser que era negado. As charges do Charlie Hebdo põe o tema da tolerância em pauta, mas não se trata necessariamente de tolerância religiosa. Viu-se que a religião não estava por trás dos motins urbanos de 2005. Agora, nos assassinatos dos jornalistas e demais vítimas, matou-se em nome de Alá, e a França revoltou-se contra o manto do sagrado. Porém, o que há sob as vestes? O que se verá se a violência for deixada nua? Aparecerá infiltrado o inimigo schmittiano, rompendo a homogeneidade da nação? Ou a França irá se deparar com incontáveis corpos abjetos, cuja existência ela continuamente expele? Há um problema de identidade a ser enfrentado.

Os corpos escuros dos novos franceses não devem continuar sendo o substrato da exclusão. Talvez seja impossível erradicar a rejeição étnica dos antigos habitantes aos imigrantes; inversamente, estes não esquecerão o quadro histórico descrito acima: invasões, espoliação, massacres. A miséria fez os exilados. "Na década de 1980, a renda de dois terços dos trabalhadores africanos estava abaixo da linha da pobreza" (GILL 1995, p. 408). Os imigrantes tornaram-se refugiados na terra dos antigos senhores, onde assimilaram novos hábitos buscando melhores condições de vida. Então, perceberam que o discurso referente às liberdades e aos direitos humanos era aplicado com desigualdade, entre outras razões porque a exclusão socioeconômica barra o acesso aos direitos. É este exercício do poder que precisa mudar, independentemente de antipatias. A igualdade política dá substância à democracia.

O discurso formado sob a bandeira do Islã foi construído tanto interna quanto externamente: dentro das periferias, prestou-se à fixação parcial das identidades, permitindo solidariedade na luta; utilizado fora delas, era uma maneira de rotular com desprezo a massa dos desfavorecidos, diferenciando-se. Quem estava fora das Zonas Urbanas Sensíveis marcava seu modo de vida dentro do país como direito ancestral, indicando que os costumes de dentro das ZUS deveriam ser postos para fora da França. Esta é a fissura da sociedade 
francesa. Dos banlieues incendiados ao Charlie Hebdo o abismo cresceu. A separação social ganhou limites mais nítidos, decorrentes da articulação de identidades em campos ainda mais antagônicos, como resultado da materialização de diferenças construídas por discursos focados na religião.

Os primitivos preconceitos contra as pessoas de ascendência africana ou árabe continuam estorvando a segunda e terceira gerações nascidas na França. Isto fez com que entre jovens descendentes de imigrantes, antes distantes da religião, tenha crescido o culto aos ensinamentos do Profeta, numa dedicação ausente em seus pais ou avós. Ressentidos pelo não pertencimento integral a um povo que tanto os acolhe quanto os expele, os novos fiéis buscam uma identidade, e não é à toa que isto se dê por intermédio da religião. Conforme acima assinalei, tal formação identitária provém de uma dicotomia duplamente constituída. $\mathrm{O}$ estigma fundamentalista colou-se aos corpos escuros ao ser aposto por quem rechaçava genericamente os imigrantes, de modo que os defensores do laicismo carregam enorme responsabilidade por transformarem um tema social num confronto religioso.

Para muitos membros das comunidades de imigrantes a religião tornou-se um meio para lutar pela dignidade e escapar da cultura dominante que constantemente humilha as famílias provenientes das ex-colônias. Através da religião diversos grupos socialmente segregados conseguiram estabelecer equivalências que identificam suas demandas, de modo necessariamente incompleto, pois seus problemas variem de comunidade para comunidade, assim como diferentes são seus corpos e etnias. Não obstante, em geral os franceses brancos consideram que os imigrantes são todos iguais, e discriminam os moradores das ZUS como muçulmanos, não importando que tenham nascido na França, e que nem todos se interessem pelo Corão. Equiparar populações provenientes do Maghreb às que vieram do Mashriq é como igualar Cartago à Fenícia: desvalorizam-se particularidades, histórias, e as variadas culturas dos imigrantes.

Nega-se a identidade francesa dos descendentes de imigrantes, impedindo-os de serem vistos como franceses, numa visão essencialista do que é ser francês. Inversamente, a presença dos imigrantes é sentida pelos franceses 'originais' como algo que modifica a identidade que sempre tiveram, insuflando uma relação antagônica: "a presença do 'Outro' impede-me de ser totalmente eu mesmo" (LACLAU; MOUFFE 2001, p. 125).

Não há receptividade para a transformação interativa das identidades, mas puro contraste de diferenças. Este antagonismo radicalizado põe a França num apartheid social expressão dura, mas que evita eufemismos, como referir-se a guetos como ZUS. Mesmo não 
sendo oficialmente reconhecida, a segregação atinge os corpos, e os que se veem como diferentes pouco ou nada se misturam. Não existem leis de isolamento social, porém as condições socioeconômicas empurram os imigrantes para os subúrbios, que o governo trata oficialmente como Zonas Urbanas Sensíveis, aonde a outra parte não vai ('no-go' zones), e até a polícia receia entrar. A separação afeta assim o comportamento sexual e matrimonial, consequência previsível onde sobressaem pretensões de pureza racial e supremacia. Questões pertinentes à sexualidade e afirmação de superioridade remetem aos estudos da construção do gênero e da dominação masculina. Por isto, penso que pode ser proveitosa uma incursão nesta área para tratar da polarização da sociedade francesa. Ocorrem práticas similares: a parcela hegemônica da população constrói a parte subjugada como portadora de deficiências que a tornam inferior e inapta para o exercício da igualdade. Tentarei mostrar a semelhança entre o poder exercido nos discursos que rejeitam a sexualidade que foge ao padrão e a rejeição dos imigrantes.

Há nos discursos que limitam a aceitação e expressão dos imigrantes um paralelismo com as construções discursivas apontadas por Butler ao tratar da materialização da heterossexualidade e da diferença sexual na construção do gênero. A apropriação que faço da análise de Butler para tratar da divisão do povo francês encontra eco em Bodies that matter (1993), onde ela discute o "tabu contra a mestiçagem" e "a regulação de uma reprodução racialmente pura":

E, se bem que existam claras razões históricas para manter a 'raça', a 'sexualidade' e a 'diferença' sexual em esferas analíticas separadas, também há urgentes e significativas razões históricas para se perguntar como e onde deveríamos interpretar não só a convergência de tais esferas, mas os locais nos quais nenhuma delas pode constituir-se sem as outras (BUTLER 2002, p. 242).

A analogia apoia-se na tentativa de responder uma questão inicial formulada pela autora: se "as palavras só por si têm o poder de modelar os corpos em virtude da sua própria substância linguística" (BUTLER 2002, p. 12). Espero ter indicado acima que não só a materialidade das ZUS resulta de formações discursivas da sociedade francesa, como também que o tratamento dado aos corpos dos imigrantes é fruto de uma construção. Os corpos escuros rejeitados não têm uma essência muçulmana. Nenhum processo natural cria corpos muçulmanos: vê-se o que foi construído discursivamente, como na suposição cultural de uma raça específica dos imigrantes.

Discursos não são meras palavras escritas ou faladas, mas práticas relacionais que “constituem um sistema de posições diferenciais e estruturadas", pelas quais o poder é exercido. É o que se tem no choque entre republicanismo laico e preceitos islâmicos: "é 
suficiente que certas regularidades estabeleçam posições diferenciais para que possamos falar de uma formação discursiva" (LACLAU; MOUFFE 2001, pp. 108-9).

Isto não significa dizer o poder discursivo produz peles escuras, ou que só existem imigrantes seguidores do Corão devido aos discursos discriminatórios, mas sim que: (1) a identidade dos imigrantes não se resumia à tez morena ou às práticas religiosas muçulmanas; (2) a fé islâmica sequer entrava na identidade de muitos jovens, nem tinha maior importância para grande parte de seus pais e avós; (3) por consequência, não havia (nem há) uma essência racial islâmica dos imigrantes.

Penso que a teoria do discurso possibilita mostrar que uma inversão foi efetuada. Para evitar a expressão xenófoba e racista direta, construíram-se demarcações discursivas vinculando os corpos escuros ao Islã, materializando os imigrantes como corpos muçulmanos, posteriormente apresentados como avessos a importantes valores republicanos.

“[As] noções habituais de 'construção' parecem dificultar a compreensão de tal afirmação" (BUTLER 2002, p. 13), porque não se percebe que os discursos fazem mais do que compor concordâncias e divergências. Usualmente, os discursos produzem a sociedade como incompletude, expressando os conflitos entre os grupos formados pelas demandas sociais, num processo aberto em que a interação das demandas transforma continuamente a composição e objetivos dos grupos. O problema não é a totalidade não ser alcançada, pois isto não é uma exclusividade da França. Estritamente falando, “[a] 'sociedade' não é um objeto válido de discurso", visto que "as identidades são puramente relacionais" e, portanto, "não podem ser plenamente constituídas" (LACLAU; MOUFFE 2001, p. 111). Esta é a mobilidade sociopolítica normal, que impede a fixação de uma totalidade social.

O que distingue a sociedade francesa contemporânea são os discursos restritivos, que constroem previamente um grupo impondo limitações instauradoras tanto da normalidade esperada quanto das diferenças inaceitáveis. Desta maneira, a maioria desconsidera a minoria. Arroga-se superioridade e normatiza o ser social expelindo uma parte que é construída discursivamente com este propósito, isto é, de modo que os corpos materializados como abjetos não sejam aceitos. A dinâmica social interativa sofre uma ruptura quando um grupo é fechado a partir de fora e deixado sem expressão, na medida em que suas demandas são impedidas de alcançar o campo político. A barreira decorre da alegação de uma religiosidade exteriormente constituída, imputada aos segregados. Basta então que os discursos atribuam aos corpos muçulmanos inadequação a dispositivos constitucionais essenciais, como a liberdade de expressão e imprensa, visando atingir e desqualificar os corpos escuros. 
Neste processo enxergo construção similar à descrita por Butler na materialização da distinção dos sexos, porém aqui se separa o democrata laico do bárbaro religioso. Não se trata da hegemonia heterossexual, ou da dominação masculina sobre o feminino, mas dos esclarecidos filhos do Iluminismo frente à irracionalidade dos que recusam as amplas liberdades democráticas. Feitas as transposições, vê-se um imigrante que é construído sob medida para justificar a sujeição, a exclusão e, finalmente, a abjeção. Acompanhando o raciocínio de Butler, mutatis mutandis, nota-se que da ação performativa do francês branco surgirá o 'islamita francês', que não é nem francês nem islamita, pois não tem direito pleno à cidadania ou à religião. “[A] performatividade deve entender-se não como um 'ato' singular e deliberado, mas sim como a prática reiterativa e referencial mediante a qual o discurso produz os efeitos que nomeia" (BUTLER 2002, p. 18). Não se trata da ação isolada ou dirigida de indivíduos, mas de um procedimento continuado de reafirmação da posição hegemônica, pela "reiteração de uma norma ou conjunto de normas [... que] oculta e dissimula as convenções das quais é uma repetição" (BUTLER 2002, p. 34).

Existem teorias do discurso mais voltadas à política do que ao corporal, como as de Laclau e Mouffe, também empregadas aqui. Contudo, espero mostrar que no choque entre a comunidade francesa tradicional e os imigrantes o corpo é fator proeminente, daí a preferência teórica por Bodies that matter. A duplicidade de sentido do título — a materialidade dos corpos, perdida na tradução - deve ser lembrada. Além, é claro, de Butler falar de Corpos que importam. Nos assassinatos do Charlie Hebdo o papel da religião salta aos olhos, e parece não mais se descolar deles. É necessário olhar além. O núcleo do conflito social francês é outro - é o outro: o corpo estrangeiro sempre identificável, mesmo quando este já não é mais estrangeiro, mas francês, e deveria pertencer integralmente à comunidade dos corpos com direitos, sem carregar marcas. Não são simples características morfológicas que vinculam os corpos de imigrantes e seus descendentes à inferioridade exteriormente constituída, mas atributos que lhes são pospostos. Nada há no interior destas pessoas ou grupos que os definam assim. A discriminação alcança os poucos bem sucedidos, como relata Alexandra Loras, consulesa francesa graduada pela Sciences Po: nos aeroportos sua negritude pesa mais que o passaporte diplomático; seu marido branco passa direto, enquanto ela é par(a)da. Loras sentencia: “É importante lembrar que quando as mulheres são discriminadas em relação ao homem é o homem que desfruta dos benefícios. E quando os não brancos são discriminados são os brancos que se beneficiam" (TEDESCO; CIRENZA 2015). Com Butler é possível ampliar esta constatação para mostrar que a religião muçulmana — vista como barbarismo irracional — é colada à etnia para subjugá-la. O discurso é similar ao da 
construção do padrão heterossexual como único adequado, que trata os corpos que fogem à norma como não vivíveis, abjetos. Ou, ainda, ao discurso que agrega fraquezas ao gênero feminino para melhor subordiná-lo. Naturaliza-se uma construção discursiva. "O poder que tem o discurso para materializar seus efeitos é assim coincidente com o poder que tem para circunscrever a esfera de inteligibilidade” (BUTLER 2002, p. 267).

Quando o racismo é simbolicamente travestido com roupagem religiosa fica fácil denunciar sem custos morais a ausência de espírito cívico e democrático do outro, pois o espectro místico assim elaborado é intangível, incorpóreo — portanto, inassimilável à cor da pele. A aplicação do estigma religioso propicia um ganho discriminatório duplo: (1) permite que se pratique a rejeição do imigrante sem ser um mau cidadão, pois não se nomeia a etnia e a repulsa que o corpo escuro do outro causa; logo, não se fere a igualdade legal de todos. (2) Esta operação converte o discriminador no bom cidadão, como defensor das normas constitucionais que prescrevem um Estado laico com liberdade de expressão.

O problema é que se a construção materializa o imigrante como seguidor do Corão, esta é a identidade social com a qual ele passa a conviver. O deslocamento do conflito do corpo escuro, com pele étnica, para o corpo muçulmano, com manto religioso, exclui o elemento humano universal e opõe dois particulares inarticuláveis, o laico e o religioso. A continuidade da fixação das identidades emperraria de vez o jogo relacional que deveria constituí-las:

[Não] haveria interação política possível: teríamos apenas uma complementaridade de diferenças totalmente não antagonística ou totalmente antagonística, em que as diferenças seriam inteiramente desprovidas de qualquer comensurabilidade, cuja única resolução possível seria a destruição mútua dos adversários (LACLAU 2011, p. 99).

\section{Nem igualdade, nem fraternidade}

A liberdade de expressão e a laicidade são afirmações da cultura hegemônica francesa anteriores ao crescimento dos fluxos migratórios; não tem sentido vê-las como barreiras propositais. Porém, deveriam vir acompanhadas da "igualdade perante a lei de todos os cidadãos sem distinção de origem, de raça ou de religião" "11 o que não ocorre de fato. Viu-se que o respeito formal à cláusula foi contornado por um estigma seletivo: mistificou-se e misticizou-se a proveniência étnica dos descendentes de imigrantes nascidos na França pela construção dos corpos escuros como corpos muçulmanos, visando recusar-lhes a identidade existencial francesa. Agora, ao debochar de Alá ataca-se a diferença escolhida para 
caracterizar o outro, cuja percepção de si mesmo não é completamente voluntária, mas dependente de um exterior constitutivo, que condiciona sua identidade.

Relembre-se a fúria dos muçulmanos por ocasião dos desenhos dinamarqueses de 2005, satirizando o Profeta: "Nas caricaturas condensou-se uma grande quantidade de humilhações e frustrações. Tal condensação, não podemos esquecer, é um fato fundamental da linguagem, da construção e imposição de certo campo simbólico" (ŽIŽEK 2014, p. 59). O jornal que os publicou era pequeno e distante, e muita gente que ficou furiosa sequer os viu, como observou Žižek. Desde então dois fatores pioraram a situação: as revoltas dos Banlieues incendiados $^{12}$, que acentuaram a associação dos imigrantes ao Islã incivilizado; e a crise econômica de 2008, que agravou o desemprego e as dificuldades enfrentadas pelos moradores das ZUS. Quando o Charlie Hebdo voltou a escarnecer a fé muçulmana, a materialização da divisão social com base religiosa intensificara-se. Por isto, o que antes era blasfêmia atacando a religião passou a ser também ofensa à identidade construída para o imigrante pela parcela hegemônica da população.

Reciprocamente, o processo também delimitou a identidade do francês tradicional, que recusou as diferenças caracterizadoras do outro: "o sujeito constitui-se através da força da exclusão e da abjeção, uma força que produz um exterior constitutivo do sujeito, um exterior abjeto que, depois de tudo, é 'interior' ao sujeito como seu próprio repúdio fundacional" (BUTLER 2002, p. 20). Os discursos que materializam o corpo muçulmano tentam preservar as condições de pertencimento à naturalidade francesa, não permitindo que novos elementos (ou tons de pele) venham alterar sua 'pureza' identitária. Ao mesmo tempo, os discursos permitem reafirmar a democracia como regime de proteção das liberdades fundamentais. Defesa que evidentemente é falha, incompleta, visto solapar a igualdade política com seu conteúdo oculto de intolerância racista e religiosa. Isto não significa que tudo seja feito como manipulação objetivamente dirigida. Já foi dito que os discursos não são ações individuais conscientemente direcionadas a uma construção intencional. Eles se originam do desejo de conservar uma identidade francesa em vias de desaparecer, o que causa insegurança em quem sempre se reconheceu a partir de um paradigma étnico-cultural bem demarcado. A identidade depende do estabelecimento de diferenças, daí a necessidade de dar um nome à existência do outro. "A denominação é ao mesmo tempo um modo de fixar uma fronteira e também de inculcar repetidamente uma norma" (BUTLER 2002, p. 26).

Ao longo desta analogia com a descrição que Butler faz da construção do sexo espero ter evidenciado o modo pelo qual materialização similar opera nos discursos que desqualificam os imigrantes sem nomear suas etnias. Aqui, o lado oprimido recebe uma 
identidade islâmica construída para subjugá-lo. Não há preocupação de apresentar o imigrante como ser humano, como pessoa merecedora de igual respeito e inclusão social:

\begin{abstract}
Como essa materialização da norma na formação corpórea [produz] um domínio de corpos abjetos, um campo de deformação que, ao não alcançar a condição de plenamente humano, reforça aquelas normas reguladoras? Que oposição poderia oferecer o âmbito dos excluídos e abjetos à hegemonia simbólica que obrigasse a rearticular radicalmente aquilo que determina os corpos que importam [bodies that matter], que estilos de vida se consideram "vida", que vidas vale a pena proteger, que vidas vale a pena salvar, que vidas merecem que se chore sua perda? (BUTLER 2002, p. 39).
\end{abstract}

Os corpos muçulmanos são inapropriados ao gozo da cidadania francesa. Despojados da sua materialidade própria, deslocam o problema da aceitação social para o da tolerância religiosa. Retomo aqui a pergunta acima formulada, quanto aos assassinatos no Charlie Hebdo semearem revolta contra o manto do sagrado: 'o que se verá se a violência for deixada nua?' Penso que o desnudamento faria ver os corpos escuros e seus guetos, cansados de esperar pela cidadania real, sem igualdade política efetiva, sobrevivendo num apartheid remodelado, em zonas de concentração. Retorna-se à cisão entre 'nós' e 'eles', forma antiga de circunscrever os bárbaros pelo não pertencimento à cultura comum: "a origem definitiva da barbárie é a própria cultura, a nossa identificação direta com uma cultura particular que nos torna intolerantes perante as outras culturas" (ŽIŽEK 2014, p. 116). Na dividida França atual, quem pratica a barbárie?

Em época distante, os gauleses foram chamados de bárbaros por decepar as cabeças dos adversários e amarrá-las aos pescoços dos seus cavalos, para humilhar os corpos dos vencidos, muito semelhantes aos dos vencedores: "assim fazendo eles se recusavam a tratá-los como seres parecidos com eles mesmos, negando que pertencessem à mesma humanidade que eles" (TODOROV 2010, p. 17). Era necessário rebaixar o rival. Quem acha que no Ocidente isto é parte de uma história distante deve recordar Guantánamo, ou Abu Ghraib: o desrespeito aos direitos dos prisioneiros é "justamente a marca da sua exclusão" (ŽIŽEK 2014, p. 136), que leva à tortura com humilhação. Guantánamo é a negação da Declaração de Direitos do Homem. Abu Ghraib serviu aos invasores norte-americanos para prisões aleatórias, sem acusações formais. Gravaram-se torturas como espetáculos para audiências sádicas: "são fotos de pessoas majoritariamente sem rosto e sem nome [...] Sua ocultação e apagamento torna-se o sinal continuado do seu sofrimento e da sua humanidade" (BUTLER 2009, p. 94). Os maustratos ou os cerca de dois milhões de mortos na Guerra ao Terror não ensejaram marchas em 
defesa dos direitos e liberdades na França, que dá suporte aos ataques. Não protestando com igual vigor os franceses aparentemente esquecem as consequências da colaboração com regimes abusivos.

Por alguns anos a França de Vichy implantou leis racistas. A discriminação era ampla: além de judeus, ciganos, homossexuais, etc., perseguiram-se os metecos, denominação dos estrangeiros provenientes do sul do Mediterrâneo, berço da maioria dos imigrantes. O lema de 1789 foi substituído por Travail, Famille, Patrie, concebido para limitar os valores anteriores e permitir que muitos fossem excluídos dos três novos ideais. Vencido o nazismo, a França recuperou a divisa revolucionária — Liberdade, Igualdade e Fraternidade. Contudo, as restrições de Vichy parecem subsistir. Os imigrantes estão sem Trabalho, sem lar decente para a Família, e vivendo numa terra que não os acolhe como Pátria. Em tempos mais recentes a xenófoba Frente Nacional reapropriou-se do termo métèque para segregar, motivando o repúdio de Nicole Loraux: "uma análise da identidade do cidadão de Atenas me permitiu igualmente observar que sem dúvida era preferível ser meteco em Atenas que imigrante na França dos anos 1990” (LORAUX apud CHÁVEZ 2011, p. 249).

Atualmente, sob o véu do confronto religioso criou-se um campo de exclusão. Os habitantes da França devem decidir se viverão como inimigos em guerra social, ou se atenuarão o confronto tratando-se como adversários legítimos, o que faria o elemento político aflorar, expondo ao debate os distintos elementos dispersos nas várias dimensões do antagonismo social. Se a França quer que prevaleçam seus valores republicanos não deve segregar imigrantes materializando uma divisão religiosa: precisa evitar o tipo de discurso antagonístico que constrói o outro como muçulmano, desconsiderando elementos essenciais da cultura trazida pelos imigrantes. Isto daria às novas etnias francesas identidades muito mais ricas do que as centradas no Corão, abrindo caminhos à interação social. O número de seguidores do Islã é crescente nas ZUS, mas a responsabilidade por tal expansão não reside apenas nos habitantes dos guetos, pois o estereótipo do muçulmano atrasado, como identidade para imigrantes, não foi uma iniciativa dos franceses rejeitados. Quando as demandas sociais dos mais carentes são repelidas como divergências assentadas em bases religiosas fecha-se o espaço político de negociação. Esquece-se a igualdade e a fraternidade republicana. Justiça social, com moradias dignas e iguais oportunidades educacionais e profissionais, favorecerá mais a tolerância do que discursos iluministas acerca das liberdades.

\section{Democracia - pluralismo e conflito}


O problema da França ultrapassa os posicionamentos divergentes. Num regime pluralista o confronto está presente, marcando uma divisão 'nós’/‘eles'. Mas a distinção não pode ser "o mero reconhecimento de limites já existentes": de um lado, a cultura tradicional francesa; do outro, a variedade cultural dos imigrantes. Precisa-se reconhecer que "certas diferenças são construídas como relações de subordinação e deveriam, portanto, ser recusadas por uma política democrática radical” (MOUFFE 2009, p. 54). Algumas diferenças não deveriam existir, enquanto outras necessitariam aparecer. Há equívoco na aculturação dos imigrantes, se com isso se quer dizer: (1) conversão destes ao padrão hegemônico da cultura branca, renunciando aos seus costumes; (2) não adaptação da França à cultura dos imigrantes, visando conservar a pureza da essência francesa.

Um povo não se constrói só com homogeneidade, como queria Schmitt. "Não há nada de automático no aparecimento de um "povo",, observa Laclau. "As razões para isso são claras: as identidades políticas são o resultado da articulação (tensão) de lógicas opostas de equivalência e diferença" (LACLAU 2007, p. 200). Na França tem-se visto apenas choque de diferenças, sem a interação que poderia rearticular e transformar identidades sociais.

Negar expressão ao político transfere reivindicações sociais para terrenos impróprios, como o da religião. "Uma verdadeira intervenção política nunca é meramente opositiva; ela é, antes, um deslocamento dos termos do debate, que rearticula a situação em uma nova configuração" (LACLAU 2014, p. 176). A contenda entre posicionamentos antagônicos é o próprio ato político de formação continuada do povo. Não existe uma forma única de democracia, e a França não tem alternativa senão reinventar a sua, que não tem funcionado haja vista a massiva exclusão social dos imigrantes, afora o crescente precariado. Os imigrantes não têm sido incluídos com igualdade no povo francês, pois são antes sujeitos submetidos a exigências do que portadores de direitos constitucionais. A ênfase na identificação dos imigrantes como muçulmanos, construindo-os como inaptos para as liberdades democráticas, propicia que a maioria (ou elite governante) tome atitudes antidemocráticas, aprisionando os imigrantes nas margens da vida política.

Os distúrbios de 2005 exibiram a insatisfação por este confinamento, demonstrando cansaço com abusos sofridos em silêncio. O perigo da coação continuada é não mais se reconhecer como violência, acomodando-se como direito adquirido. Embora os motins não tenham sido comandados por organizações islâmicas, muitos jovens acabaram cooptados pelo fundamentalismo religioso, canalizando a opressão sociopolítica para seus próprios fins. O que se viu nos banlieues incendiados foi a defesa de um espaço, com a fúria direcionada a 
bens materiais. Desde então, quase nada foi feito para desarmar os ânimos. Dez anos depois, no ataque ao Charlie Hebdo, insatisfeitos recrutados e bem treinados não queriam apenas ser ouvidos. Impuseram silêncio, pela atitude antissocial extrema: matar quem incomoda. Os assassinatos não aumentam a força dos mais fracos, nem melhoram a vida deles, mas impõe medo ao outro lado - ao poder.

Podem-se empregar adjetivos e advérbios à vontade para repudiar o ataque ao Charlie Hebdo. As qualificações do inaceitável não atenuarão a extensão do mal desencadeado. Quando a ordem social é quebrada porque os discordantes desistem dos meios legais de manifestação, passando a julgar sem permitir defesa e matar sem receio de morrer, a insegurança contamina a sociedade. Então, é como se a guerra de todos contra todos fosse real, e a morte violenta espreitasse o dia a dia de qualquer cidadão. O terror estende a violência social dissimulada, sofrida pela fração rejeitada da população, a todos os franceses.

\section{Conclusão - liberdades e inclusão}

Logo no início perguntei: 'Por que a defesa dos valores democráticos costuma começar associando a democracia à liberdade, e não à igualdade'? A liberdade só será um valor para todos se cada um for igualmente considerado, tornando-se capaz de usufruí-la.

\footnotetext{
A satisfação das necessidades básicas de um indivíduo é uma condição necessária para a autoestima do indivíduo, para seu respeito pelos demais e pelo respeito aos princípios da sociedade. Enquanto suas próprias necessidades básicas não são respeitadas, não é razoável esperar que o indivíduo se identifique com as normas da sociedade (DIAS 2004, p. 96).
}

Não se solucionará o conflito francês reprimindo a liberdade de imprensa. No Ocidente há diversas restrições a tal direito, como sabem Edward Snowden e Julian Assange (WikiLeaks). Mesmo sem censura prévia, casos de injúria e difamação são puníveis. Foi assim que a World Union of Muslim Scholars classificou as caricaturas dinamarquesas: is ā'ah - insulto, dano, ofensa (ASAD 2009, p. 38), termo aplicado em contexto secular, diferentemente de blasfêmia. Proíbe-se a publicação de pornografia infantil, e de textos com direito autoral sem autorização, lembra Asad. Nenhum direito ou liberdade é absoluto, sempre há limitações. A meu ver, o recriminável nas charges é atacarem oprimidos: rejeitados com falsa desculpa religiosa, explorados em guerras que o Ocidente impõe ao Oriente Médio e à África. Penso que seria sensato as mídias evitarem agressões gratuitas que nada acrescentam em termos de conhecimento. 
É questionável a superioridade absoluta da civilização ocidental. Para o modelo de governo criado no Ocidente, foi uma conquista separar Estado e Igreja, pondo fim a longo morticínio de motivação teológica. Estranhamente, alguns países aceitam crucifixos nos tribunais e bênçãos no dinheiro — nas duas proteções do cidadão.

Respeitar a igualdade humana permitiria valorizar a diversidade étnica e sua expressão, sem acusar a religião para ocultar o racismo. Imigrantes são humanos, pessoas iguais em direitos. Na Carta acerca da tolerância (1689) Locke rejeita os ateus. Atualmente, ocorre inversão, parecendo que a laicidade autoriza ofender o sagrado. Apesar do deslize intolerante de Locke, merece lembrança o final da carta: "Não é pelo fato de os homens se agruparem em torno de uma religião que se dividem em facções antagônicas, mas porque a opressão os torna miseráveis" (LOCKE 1978, p. 25).

Enfim, considerando os eventos históricos, é difícil "entender exatamente o que se pretende dizendo que 'democracia' e 'livre expressão' são intrínsecos à 'civilização europeia', e desigualdade e repressão são atribuídos à "civilização islâmica"” (ASAD 2009, p. 24). Uma imprensa livre de fato, que não esteja a serviço dos poderes hegemônicos, poderia contribuir para reduzir este tipo de desinformação. A Revolução francesa foi seguida pela redefinição do mapa europeu, por guerras e expansão imperialista, ontem e hoje ‘justificadas' como libertação de povos oprimidos, em nome dos ideais revolucionários. São promessas não concretizadas mesmo no interior dos países europeus mais ricos. Reitero: assegurar direitos sociais básicos é condição fundamental para efetivar direitos políticos:

[...] dominação significa a tentativa de proteger algumas pessoas da precariedade existencial, enquanto ao mesmo tempo este privilégio da proteção é baseado na distribuição diferencial da precariedade para todos aqueles que são percebidos como o outro e considerados como menos merecedores de proteção (LOREY 2015, p. 22).

A democracia francesa está numa encruzilhada no que tange à igualdade. Na verdade, o próprio projeto da União Europeia deteriora-se "devido aos interesses de um pequeno grupo de elites nacionais" (MOUFFE 2013, p. 52). Mundo afora, a enorme concentração de riqueza (PIKETTY 2014) gera cada vez mais exclusão social. Na França de Luís XVI não foi pela religião que o povo enfrentou o clero e a nobreza, mas pelo fim dos privilégios, por direitos. "Devemos redescobrir o espírito de 1789. Senão, alguns podem eventualmente querer redescobri-lo literalmente, com suas implicações sangrentas" (CANET; PECH; STEWART 2008, p. 17). 


\section{Notas:}

${ }^{1} \mathrm{O}$ inimigo está na "alteridade do estrangeiro", ameaçando a coesão interior. Schmitt apela à igualdade sem constituí-la politicamente; desvela antagonismos, situando-os exteriormente. Exclui a discordância interna e o pluralismo democrático, sem construir o político e a igualdade (Mouffe 2005a).

${ }^{2}$ Al-Maghrib - poente, ocidente. Pequeno Magrebe/Magrebe Central: Marrocos, Saara Ocidental, Argélia e Tunísia. Grande Magrebe: mais Mauritânia e Líbia. Al-Mašriq - nascente, oriente: Egito ao Iraque e Península Arábica.

3 Atlas des Zones Urbaines Sensibles, refere-se a mapeamento oficial realizado pelo governo francês. http://sig.ville.gouv.fr/Atlas/ZUS/.

${ }^{4}$ Ver, por exemplo, o estudo de Canet, Pech e Stewart.

${ }^{5}$ Constituição Francesa (4/10/1958), artigo 1 ${ }^{\circ}$ : "La France est une République indivisible, laïque, démocratique et sociale. Elle assure l'égalité devant la loi de tous les citoyens sans distinction d'origine, de race ou de religion. Elle respecte toutes les croyances. [...]"

6 Desemprego mais alto entre jovens descendentes de imigrantes também ocorre na Alemanha, Reino Unido, Itália, Bélgica e Espanha. Assim como na França, tais etnias têm educação deficiente e pouca representação política, sendo raras nos estratos sociais elevados.

${ }^{7}$ Seguidor(a) da Jihad.

8 The Chapters on Jihad, Arabic ref.: Book 24, Hadith 2899. http://sunnah.com/ibnmajah/24.

9 “...nada será feito que possa atentar contra os direitos civis e religiosos das coletividades não judaicas existentes na Palestina...”. https://www.jewishvirtuallibrary.org/jsource/History/ baltoc.html.

${ }^{10}$ Após as eleições de 2007, dos 555 membros do Parlamento apenas 4 eram imigrantes; no Senado, apenas 5 em 305 (Michon 2011).

${ }^{11}$ Constituição Francesa, supracitado.

${ }^{12}$ Os distúrbios iniciaram em Paris em 27/10/2005, decorrerentes da violência policial supracitada. Embora posteriores às charges do Jyllands-Posten (30/09/2005), não tiveram ligação direta com estas. 


\section{Referências bibliográficas:}

ADIDA, Claire; LAITIN, David D.; VALFORT, Marie-Anne. Identifying barriers to Muslin integration in France. In Proceedings of the National Academy of Sciences, vol. 107, $\mathrm{n}^{\mathrm{o}} 52$, November 22, 2010. http://www.pnas.org/content/107/52/22384.full.pdf.

ASAD, Talal. On suicide bombing. New York: Columbia University Press, 2007.

ASAD, Talal et alii. Is critique secular? blasphemy, injury, and free speech. Berkeley: UCLA, 2009. (The Townsend papers in the humanities, $n^{\circ} 2$ )

BAUDRILLARD, Jean. The pyres of autumn. In New Left Review, 37, January-February 2006. http://newleftreview.org/II/37/jean-baudrillard-the-pyres-of-autumn.

BOLTANSKI, Luc; CHIAPELLO, Ève. O novo espírito do capitalismo. Tradução de Ivone C. Benedetti. São Paulo: WMF Martins Fontes, 2009.

BUTLER, Judith. Cuerpos que importan: sobre los límites materiales y discursivos del "sexo". Traducción de Alcira Bixio. $1^{\mathrm{a}}$ ed. Buenos Aires: Paidós, 2002. (Género y cultura)

. Frames of war: when is life grievable? London: Verso, 2009.

CANET, Raphaël; PECH, Laurent; STEWART, Maura. France's Burning Issue: Understanding the Urban Riots of November 2005. In Social Science Research Network, November 18, 2008. http://papers.ssrn.com/sol3/papers.cfm?abstract id=1303514.

CESARI, Jocelyne. Ethnicity, Islam, and les banlieues: confusing the issues. In Riots in France Essay Forum. New York: Social Science Research Council, 2005.

http://riotsfrance.ssrc.org/.

CHÁVEZ, Silvia. Loraux, Nicole, Nacido de la tierra.Mito y política en Atenas. (Reseña). In Noua Tellus, 29-1. México (D.F.): UNAM, 2011. pp. 241-250.

http://www.iifilologicas.unam.mx/nouatellus/uploads/volumenes/nt-291/nacidodelatierra 29$\underline{1 . p d f}$.

CÍCERO, Marco Túlio. Da república. Tradução de Amador Cisneiros. $2^{\mathrm{a}}$ ed. São Paulo: Abril Cultural, 1980. (Os Pensadores)

DIAS, Maria Clara. Os direitos sociais básicos: uma investigação filosófica da questão dos direitos humanos. Porto Alegre: EDIPUCRS, 2004. (Coleção Filosofia, $\mathrm{n}^{0} 177$ )

GILL, Stephen. Globalisation, market civilization and Disciplinary Neoliberalism. In Millennium - Journal of International Studies, 1995, 24, pp. 399-423. http://mil.sagepub.com.

GORLICK, Adam. Stanford study shows Muslim job discrimination in France. In Stanford Report, November 22, 2010. http://news.stanford.edu/news/2010/november/muslim-francestudy-112210.html.

LACLAU, Ernesto. On populist reason. London; New York: Verso, 2007. 
EdUERJ, 2011.

Emancipação e diferença. Tradução de Joanildo A. Burity et alii. Rio de Janeiro: The rethorical foundations of society. London: Verso, 2014.

LACLAU, Ernesto; MOUFFE, Chantal. Hegemony and socialist strategy: towards a radical democratic politics. $2^{\text {nd }}$. ed. New York: Verso, 2001.

LOCKE, John. Carta acerca da tolerância. Tradução de Anoar Aiex. 2a ed. São Paulo: Abril Cultural, 1978. (Os Pensadores).

LOREY, Isabell. State of insecurity: government of the precarious. Translated by Aileen Derieg. London: Verso, 2015.

MICHON, Laure. Immigrants in French politics. In Heinrich-Böll-Stiftungen, September 2011. http://heimatkunde.boell.de/node/14865.

MILL, John Stuart. A liberdade. Tradução de Eunice Ostrensky. São Paulo: Martins Fontes, 2000. (Clássicos).

MOUFFE, Chantal (Org.). Dimensions of radical democracy: pluralism, citizenship, community. London, New York: Verso, 1992.

. The return of the political. London, New York: Verso, 2005a. (Radical Thinkers).

. On the political. London, New York: Routledge, 2005b. (Thinking in Action).

. The democratic paradox. London; New York: Verso, 2009. (Radical Thinkers).

. Agonistics: thinking the world politically. London; New York: Verso, 2013.

PIKETTY, Thomas. O capital no século XXI. Tradução de Monica Baumgarten de Bolle. Rio de Janeiro: Intrínseca, 2014.

PONS, Vincent; LIEGEY, Guillaume. Increasing the Electoral Participation of Immigrants: Experimental Evidence from France. Cambridge (MA): MIT, 2013.

http://economics.mit.edu/files/8885.

TEDESCO, Cândida Del; CIRENZA, Fernanda. Alexandra Baldeh Loras: uma consulesa além dos brioches. In Revista Brasileiros, 19/02/2015. http://brasileiros.com.br/2015/02/umaconsulesa-alem-dos-brioches/.

TODOROV, Tzvetan. The fear of barbarians: beyond the clash of civilizations. Translated by Andrew Brown. Chicago: University of Chicago Press, 2010.

ŽIŽEK, Slavoj. Some politically incorrect reflexions on violence in France. In:Dossier IPAM, Le soulevement populaire dans les banlieues françaises d'octobre-novembre 2005. Paris:

IPAM, 2005. http://www.reseau-ipam.org/IMG/pdf/Dossier IPAM Revoltes urbaines.pdf. 
. Violência: seis reflexões laterais. Tradução de Miguel Serras Pereira. São Paulo: Boitempo, 2014. 